\title{
ASSESSMENT OF RESIDENTS' ACCESSIBILITY TO INFRASTRUCTURE IN ILORIN METROPOLIS
}

\author{
Nurudeen Adesola MALIK * \\ University of Ilorin, Department of Geography and Environmental Management, \\ Ilorin, Kwara State, Nigeria, e-mail: today_2009@yahoo.com \\ Philips Ayokanmi TAIWO \\ University of Ilorin, Department of Geography and Environmental Management, \\ Ilorin, Kwara State, Nigeria, e-mail: philipscore@yahoo.com \\ Olanrewaju Yusuf YAHAYA \\ Federal University Dutsin-Ma, Department of Geography and Regional Planning, \\ Dutsin-Ma, Katsina State, Nigeria, e-mail: yyahaya@fudutsinma.edu.ng
}

\begin{abstract}
Citation: Malik, N.A., Taiwo, P.A., \& Yahaya, Y.O. (2021). Assessment of Residents' Accessibility to Infrastructure in Ilorin Metropolis. Analele Universității din Oradea, Seria Geografie, 31(1), 11-21. https://doi.org/10.30892/auog.311102-834
\end{abstract}

\begin{abstract}
The existence of an efficient accessible and reliable infrastructure does not only serve as booster to the development of trade and interchange of a modern urban economics but it also inspires life through healthy living. This study examines the residents' access to piped water and sanitation facilities (Roro-bins) in Ilorin metropolis. Both primary and secondary sources of data including questionnaire administration, documents in government agencies and journal articles were used for the study. A systematic-random sampling technique was adopted in the selection of 408 respondents from the selected households. Descriptive statistics such as tables, cross tabulations, charts and mean were used to analyze the data. The findings of the study revealed poor access of the residents to sanitation facilities and the residents were also poorly served with piped water; these two life enhancing facilities were not evenly distributed in the study area; many of the residents are stressed before accessing the facilities as majority spend above 30 minutes and walk a long distance before getting to the nearest piped water facility. The study suggests a need for social change from poor waste disposal attitude and the provision of more boreholes within the reach of the public to serve as alternative to piped water.
\end{abstract}

Key words: assessment, residents, infrastructure, Ilorin metropolis, Nigeria

$$
* \quad * \quad * \quad * * * *
$$

\section{INTRODUCTION}

The word population as a whole has been experiencing an unprecedented urban growth. The rate of increase in urban population has exceeded the overall population for at least two centuries (United Nations, 2014). The level of urban growth however varies among regions of the 
world. In 1976, 38\% of the world's population lives in the urban areas. Today, $55 \%$ of the world's people are in the urban areas. This proportion is expected to increase to 68 percent by 2050 (UN DESA, 2018). In Nigeria, unlike most African countries, it can be said that the nation is undergoing a period of rapid urbanization which is preceded by industrialization and rapid economic development. The growing urban population is mainly absorbed in the low paid informal sector while others are unemployed. It was noted that the level of urban growth in Nigeria rose from $4.8 \%$ in 1921 to an estimated $31.77 \%$ in 1985 (Ogu, 2009). This size of the urban population and its attendant expansion in the next few decades has huge implications for provision and access to infrastructure and development (Akinyosoye, 2011; Ogu, 2009). For instance more than 700 million people still lack ready access to improved sources of drinking water; nearly half are in sub-Saharan Africa. More than one third of the global population (some 2.5 billion people) do not use an improved sanitation facility, and of these 1 billion people still practice open defecation (World Health Organization, 2020).

In Nigeria, the growths of urban areas however are replete with several cases of inadequate infrastructure. These include irregular supply of electricity, shortage of piped water, fuel scarcity, unreliable health care services, unstable educational institutions, bad roads, malfunctioning ports and erratic telecommunications (Akinwale, 2010). The poor access to selected social indicators of improve sanitation, improve water source, health care services, transportation services among others are magnified by the inadequacies experienced in the provision of infrastructure needed in the urban Nigeria (World Bank, 2003). The replete state of sanitation facilities in Ilorin have led to sites of heaps of waste in the city and this has since became unbearable especially in the neighborhood of commercial areas such as open markets, and motor garages (Ajibade, 2008).

Dahlgren (2008) observed that accessibility to facilities is dependent on several parameters. Accessibility is defined as the cost to access a specific set of public infrastructures including piped water and sanitation facilities among others. The accessibility is measured as travel distance along a road, in time or space (Dahlgren, 2008).

One of the challenges facing Nigeria in the wake of urban growth in the past few decades is the planning and management of physical infrastructures and the urban environment. The facts of this matter are that the location of these infrastructures are rarely planned to fix the needs of the people. This essentially woke the problem of accessibility, inadequacy of infrastructure services, inequality, deprivation and the deteriorating urban environment (Ogu, 2009). It cannot be overemphasized that the quality and coverage of infrastructure services such as electricity, water, sanitation, telecommunications and transport have a major impact on living standards and economic growth (Penelope and Warrick, 2001). Therefore, given the importance of infrastructure services at facilitating the efficiency of production and the means through which the process of development and growth can be undertaken as noted by Rutto (1997), it becomes necessary to attempt the study of the resident's access to infrastructural facilities in Ilorin metropolis.

\section{The Study Area}

Ilorin, the capital of Kwara State is located on latitude $8^{0} 30^{\prime} \mathrm{N}$ and longitude $4^{0} 35^{\prime} \mathrm{E}$ (figure 1). It occupies an area of about $100 \mathrm{~km}^{2}$ and is located about $300 \mathrm{~km}$ from Lagos and $500 \mathrm{~km}$ from Abuja (Oyebanji, 1993 cited in Banji, 2015). The metropolis covers about 3 Local Government Areas (LGAs) out of the sixteen LGAs that make up kwara State and it is bounded to the North by Moro LG; Asa LG to the East; Ifelodun LG to the West; and Oyun LG to the South (figure 1). Ilorin developed as an administrative centre. However in the recent times, both economic and social activities have greatly influenced its growth. The major occupations of the people are farming, pottery making and weaving. Moreover, a greater percentage of the people are involved in trading, while others are self-employed in different fields such as mechanic, carpentry, diary vendors and transporters among others. In terms of amenities, Ilorin metropolis has various financial institution and credit houses, educational institutions and health services at all levels. There are television stations and radio houses. It is connected by road with Lagos, Ibadan, and Abuja-Lokoja, Kaiama and Kaduna. There is also a railway linking the city to the core north and southern part of Nigeria. Ilorin also has an international airport. 


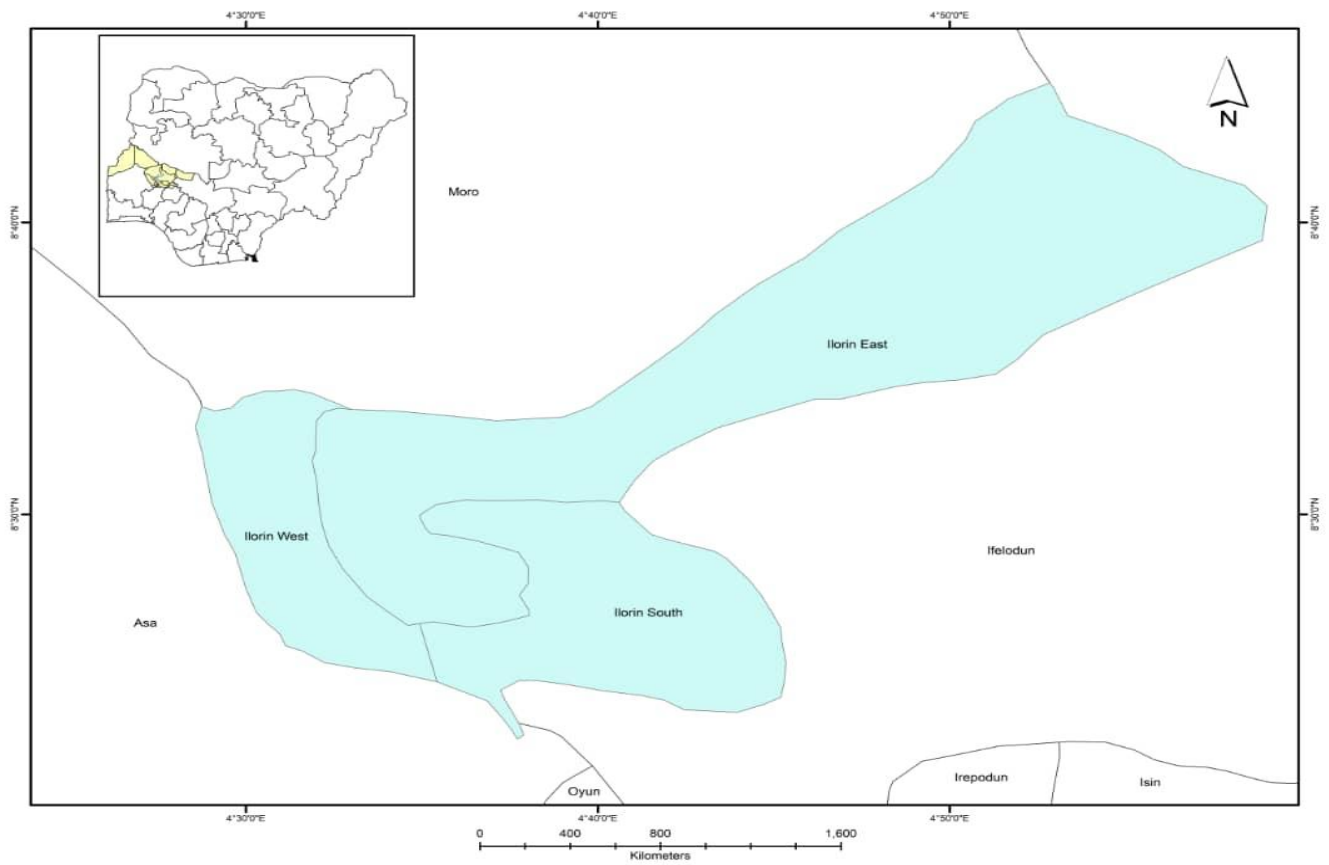

Figure 1. Ilorin Metropolis Showing the Areas Covered (Source: Modified from Kwara State Administrative Map)

\section{RESEARCH METHODS}

This study employed both primary and secondary sources of data. The primary data sources include reconnaissance survey, field observation and the administration of questionnaire while data from Kwara State Ministry of Lands, Kwara Waste Management Company (KWMC), Kwara State Water Corporation and National Population Commission were the relevant secondary data collection sources. The sample size was determined using 2014 population projection of Ilorin puts at two million five thousand and nineteen $(2,005,019)$. The Cochran (1963) $\left(n=Z^{2} a / 2\right.$.pq. $N+e^{2}(N-1)+Z^{2} a / 2$.p.q was employed to arrive at 408 copies of questionnaire. The sample size for each ward is as shown in table 1 . The administration of the questionnaire was carried out using systematic random sampling technique. The first household (respondent) is determined randomly and subsequently at an interval of three (3) houses. Descriptive statistics such as tables, cross tabulations, percentages and graphs were used to analyze the socio-economic characteristics of respondents, methods of waste disposal by respondents, access of respondents to water, regularity of water supply and factors influencing the method of waste disposal among others.

Table 1. Population of Wards in Ilorin Metropolis

Source: *National Population Commission 2006; **Adapted from Sanni (2014)

\begin{tabular}{|c|c|c|c|c|c|}
\hline S/N & Wards & $\begin{array}{c}\text { Population of } \\
\text { Wards* }\end{array}$ & $\begin{array}{c}\text { Total number } \\
\text { of household* }\end{array}$ & $\begin{array}{c}\text { 2016 household } \\
\text { projection** }\end{array}$ & $\begin{array}{c}\text { No. of household } \\
\text { sampled** }\end{array}$ \\
\hline 1. & Adewole & 43,084 & 454 & 11358 & 34 \\
\hline 2. & Ajikobi & 65,568 & 502 & 17286 & 34 \\
\hline 3. & Alanamu & 65,626 & 567 & 17301 & 30 \\
\hline 4. & Are & 54,969 & 462 & 78492 & 22 \\
\hline 5. & Baboko & 29,638 & 338 & 11162 & 32 \\
\hline 6. & Badari & 42,341 & 448 & 15666 & 34 \\
\hline 7. & Balogun Fulani & 59,425 & 451 & & \\
\hline
\end{tabular}




\begin{tabular}{|c|c|c|c|c|c|}
\hline 8. & Balogun Gambari & 37,661 & 421 & 9929 & 20 \\
\hline 9. & Ibagun & 33,872 & 405 & 8930 & 18 \\
\hline 10. & Magajin Geri & 47,614 & 429 & 12552 & 18 \\
\hline 11. & Okaka & 32758 & 365 & 2636 & 18 \\
\hline 12. & Ogidi & 25,553 & 303 & 6767 & 14 \\
\hline 13. & Oju-ekun & 30,307 & 344 & 7990 & 16 \\
\hline 14. & Oke-ogun & 29,415 & 336 & 7755 & 16 \\
\hline 15. & Oloje & 17,531 & 233 & 4622 & 10 \\
\hline 16. & Sabon Geri. I & 23,028 & 423 & 6071 & 12 \\
\hline 17. & Sabon Geri II & 19,314 & 361 & 5092 & 10 \\
\hline 18. & Ubandawaki & 66,554 & 513 & 17546 & 36 \\
\hline 19. & Zango & 36,324 & 406 & 9576 & 20 \\
\hline 20. & Zarumi & 17,085 & 304 & 4504 & 10 \\
\hline & Total & 777,667 & 8,065 & 205019 & 416 \\
\hline
\end{tabular}

\section{RESULTS AND DISCUSSION OF FINDINGS}

\section{SOCIO-DEMOGRAPHIC CHARACTERISTICS OF RESPONDENTS}

The sex and age characteristics of the respondents revealed that $59.3 \%$ are male while $40.7 \%$ are female. This ratio could be the result of the patriarchal family system practiced in most African societies in which men are heads of household to whom the questionnaire was directed. This is in line with the result of findings of Fisher (2015) in her study on efficiency of water supply in Ilorin which showed that majority $(63.7 \%)$ of the respondents were male. Similarly, the age distribution of the respondents shown in table 2 further reveals that majority $(76.4 \%)$ of the respondents are within the early adulthood age bracket, while less than $30.0 \%$ of the respondents fall within the early old age bracket.

Furthermore, $32.4 \%$ of the respondents are traders, while $25.0 \%$ and $23.0 \%$ are artisan and public servants respectively. Only $8.8 \%$ of the respondents are full house wives. This implies that most of the respondents are self-employed. Also, $54.4 \%$ of the respondents earn between N18,000$\mathrm{N} 30,000$, while $25.5 \%$ and $14.7 \%$ of the respondents earn between N31,000-N50,000 and NN50,000 and N100,000 respectively (table 2). The majority of respondents earned above the minimum wage of $\mathrm{N} 18,000$ which may be linked to the fact that a high percentage of the respondents fall within the active productive age brackets and hence they able to engage in productive economic activities that attract high income.

The family size of the respondents indicates that $57.8 \%$ of them had between four to six family member, while $16.2 \%$ and $22.0 \%$ of the respondents had between one to three and seven to nine family members respectively. This result is expected because it reveals the family type characteristic of most African communities which support polygamy, this is complemented by predominant religion practices in the study area which supports a large family size.

Table 2. Socio-Demographic Characteristics of Respondents Source: Author's Fieldwork, 2017

\begin{tabular}{|l|l|l|}
\hline Characteristics & Frequency & Percentage \\
\hline Sex & & \\
Male & 242 & 59.3 \\
Female & 166 & 40.7 \\
Total & $\mathbf{4 0 8}$ & $\mathbf{1 0 0 . 0}$ \\
Age & & \\
$18-25$ & 134 & 32.8 \\
\hline
\end{tabular}




\begin{tabular}{|l|l|l|}
\hline $26-45$ & 178 & 43.6 \\
$46-65$ & 92 & 22.5 \\
65 and above & 04 & 1.0 \\
Total & $\mathbf{4 0 8}$ & $\mathbf{1 0 0 . 0}$ \\
\hline Occupation & & \\
House wife & 36 & 8.8 \\
Public Servant & 94 & 23.0 \\
Artisan & 102 & 25.0 \\
Trading & 176 & 43.2 \\
Total & $\mathbf{4 0 8}$ & $\mathbf{1 0 0 . 0}$ \\
\hline Income (N) & & \\
<18,000 & 16 & 3.9 \\
$18,001-30,000$ & 222 & 54.4 \\
$30,001-50,000$ & 104 & 25.5 \\
$50,001-100,000$ & 60 & 14.7 \\
Above 100,000 & 06 & 1.5 \\
Total & $\mathbf{4 0 0}$ & $\mathbf{1 0 0 . 0}$ \\
\hline Household Size & & \\
$1-3$ & 65 & 16.2 \\
$4-6$ & 237 & 57.8 \\
$7-9$ & 90 & 22.0 \\
Above 9 & 16 & 4.0 \\
Total & $\mathbf{4 0 8}$ & $\mathbf{1 0 0 . 0}$ \\
\hline
\end{tabular}

Residents' Access to Water and Factors Influencing Accessibility to Water in Ilorin

The International Monitoring Organization defined access to safe drinking water as the proportion of people using improved drinking water sources. The organization further defined "access" as the availability of at least 20 liters per person per day from an improved" source within one kilometer of the user's dwelling. Access to safe water is measured by the number of people who have a reasonable means of getting an adequate amount of water that is safe for drinking, washing, and essential household activities, expressed as a percentage of the total population. Access to safe water reflects the health of a country's people and the country's capacity to collect, clean, and distribute water to consumers.

Table 3. Accessibility to Water Supply in Ilorin Metropolis

\begin{tabular}{|l|l|l|}
\hline \multicolumn{1}{|c|}{ Time Spent on Fetching Water } & \multicolumn{1}{|c|}{ Frequency } & \multicolumn{1}{c|}{ Percentage } \\
\hline Time & \multicolumn{2}{|c|}{} \\
$5-10$ minutes & 78 & 2.5 \\
11-20 minutes & 156 & 19.1 \\
21-30 minutes & 164 & 38.2 \\
Above 30 minutes & 408 & 40.2 \\
Total & & 100 \\
\hline Distance between Home and Source of Water & 200 & \\
\hline 0-1 km & 166 & 49.0 \\
-4 km & 42 & 40.7 \\
Above $4 \mathrm{~km}$ & 408 & 10.3 \\
Total & & 100 \\
\hline
\end{tabular}

Accessibility to water supply is a function of distance cover from individual household to the water point and the time taken. The result in table 3 revealed that $38.2 \%, 19.1 \%$ and $2.5 \%$ of the respondents claimed that they spend between (21-30, 11-20 and 5-10) minutes daily to get water for domestic uses. However, majority $(40.2 \%)$ of the respondents spend above 30 minutes to get water 
for daily usage. In addition, $49 \%$ of the respondents travel between $0-1 \mathrm{~km}$ to fetch while $40.7 \%$ of the respondents travel between 2-4 km. This implies that many of the respondents travelled above the minimum standard of $100 \mathrm{~m}$ travel distance to major source of water supply recommended by the UN General Assembly. This supports Oyebode (1991) findings which revealed that $75 \%$ of respondents in Ilorin walked 400-800 meters from their residences to the nearest water points. This finding also complements the work of Taiwo (2014) which shows that $81.7 \%$ of the respondents in Ilorin walk between $2 \mathrm{~km}$ and $3 \mathrm{~km}$ before getting water for daily usage.

The result in figure 2 showed that $21.1 \%, 14.7 \%$ and $3.4 \%$ of the respondents sourced their water from well, pipe borne water and water vendor respectively. However, majority $(60.8 \%)$ of the respondents sourced their water from bore hole. This implies that most of the respondents (75.5\%) sourced their water from sources which cannot be easily polluted. This agrees with the Taiwo (2014) research findings which revealed that over $50.0 \%$ of the residents in Ilorin metropolis used water from protected sources such as borehole, tap and well.

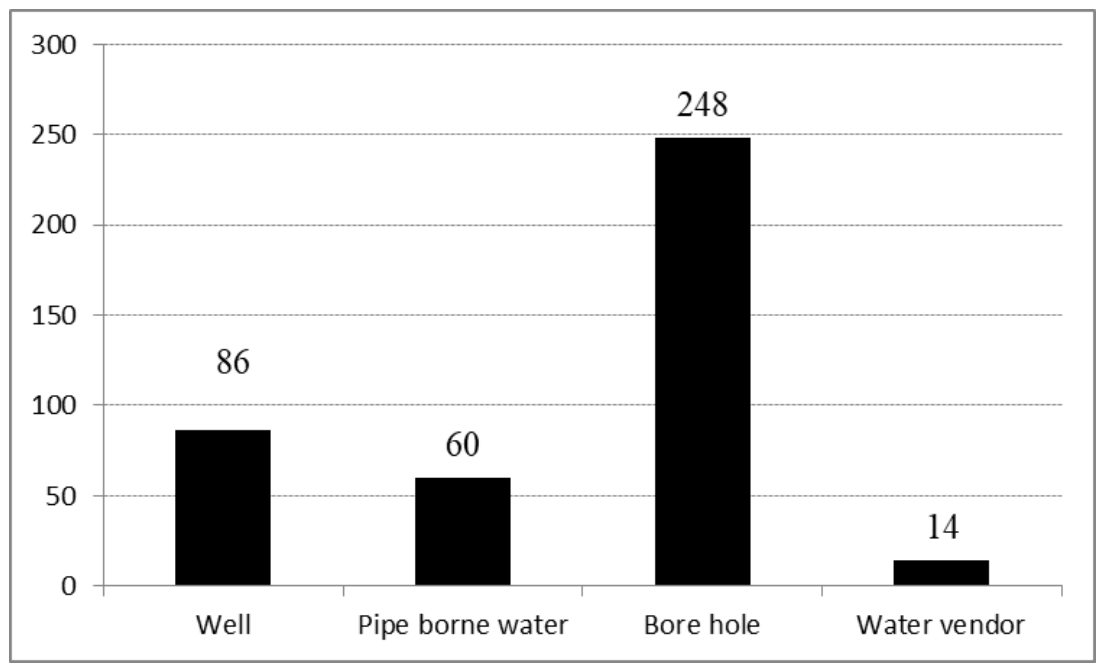

Figure 2. Sources of Domestic Water Supply Source: Author's Field work, 2017

The respondents (44.1\%) agreed that proximity of water source to their places of residences is a major factor influencing accessibility to water supply in Ilorin. This result supports the theory of distance decay which is of the idea that as distance increases, utilization of facility reduces. In addition, $35.3 \%$ and $20.6 \%$ of the respondents claimed that frequency of availability and reduced cost of sources of domestic water supply influenced their accessibility (table 3). However, majority of the respondents in the study area often disregard long distance to get water for domestic uses. This result is in consonant with figure 2 where majority of the respondents go about to get access to bore hole water that is ubiquitously spread in the study area.

Table 4. Factors Influencing Accessibility of Domestic Water Supply Source: Author's Field work, 2017

\begin{tabular}{|l|l|l|}
\hline Factors & \multicolumn{1}{|c|}{ Frequency } & \multicolumn{1}{c|}{ Percentage } \\
\hline Proximity of residence & 180 & 44.1 \\
Frequency of availability & 144 & 35.3 \\
Source is cheap and available & 84 & 20.6 \\
\hline Total & 408 & 100.0 \\
\hline
\end{tabular}




\section{Major Provider and Efficiency of Domestic Water Supply in Ilorin Metropolis}

As revealed in figure $3,13.3 \%$ of the respondents attested that individuals are the major providers of their domestic water supply, while $6.4 \%$ of the respondents identified the community as the major provider of domestic water supply in the study area. However, $79.9 \%$ of the respondents affirmed that Kwara State Water Corporation is the major water supply provider in the study area. The data show that most of the water demand in the study area is provided by the state government through Kwara State Water Corporation. This result complements that of Fisher (2015) which revealed that $56.3 \%$ of the respondents sourced water for domestic uses from the Kwara State Water Corporation, while $24.3 \%$ of the respondents got their domestic water supply from well. Moreover, government of Kwara State is so helpful to the people in the area of supplying adequate water. This is in line with the efforts of the government to achieve goal target of Sustainable Water Development Goal.

Table 4, 5 shows the efficiency of water supply in the study area. $27.9 \%$ of the respondents disagreed with the view that they have access to sufficient water for daily usage, while $9.3 \%$ of the respondent strongly disagreed to this view. Evidence to this is the result of the work of Omonona and Adeniran, (2012) which shows that only 34.4\% of sampled households in Ilorin metropolis had access to adequate water.

However, $39.2 \%$ of the respondents agreed that they have access to sufficient water for daily usage, while $39.7 \%$ of the respondents strongly agreed to this view. The high percentage may be linked to the increased efforts of the government in supplying water for domestic uses in the metropolis.

Table 5. Regularity of Water Supply in Ilorin Metropolis Source: Author's Field work, 2017

\begin{tabular}{|l|l|l|}
\hline Regularity & Frequency & Percentage \\
\hline Strongly Agree & 48 & 23.5 \\
Agree & 80 & 39.2 \\
Strongly Disagree & 19 & 9.3 \\
Disagree & 57 & 27.9 \\
\hline Total & 408 & 100.0 \\
\hline
\end{tabular}

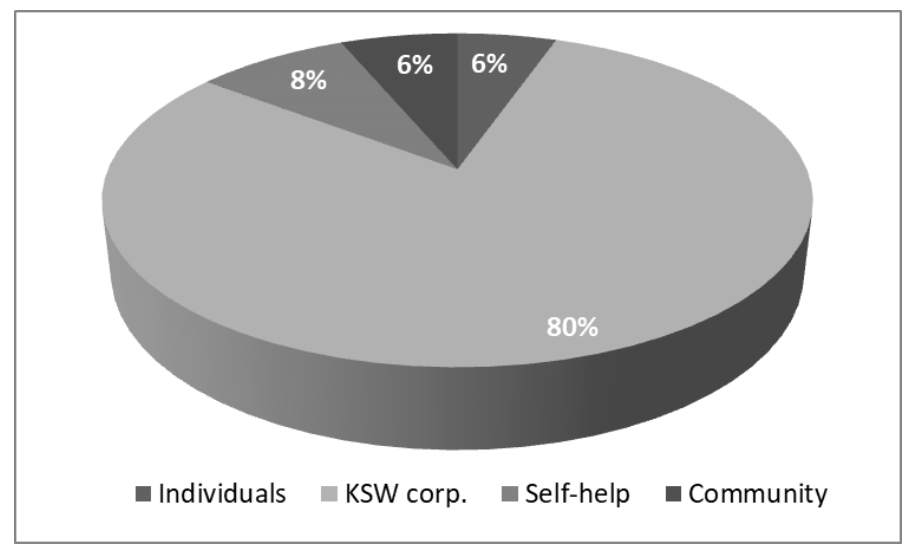

Figure 3. Major Provider of Domestic Water Supply in Ilorin Metropolis Source: Author's Field work, 2017

Methods of Waste Disposal and Factors Influencing Waste Disposal in Ilorin Metropolis

The result in figure 4 revealed that $61.0 \%$ of the respondents claimed that they disposed their waste through waste bins provided by the Kwara State Waste Management Company (KWMC), while $20.0 \%$ and $14.0 \%$ of the respondents disposed their waste on available open 
spaces within their neighbourhoods and into incinerator respectively. In addition, $5.0 \%$ of the respondents disposed their waste through private waste collectors.

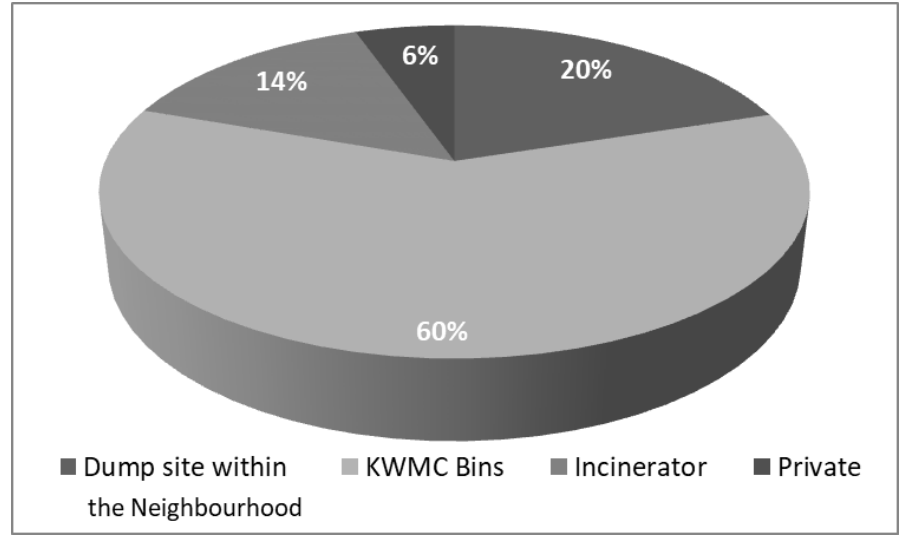

Figure 4. Waste Disposal Methods in Ilorin Metropolis Source: Author's Fieldwork

Furthermore, the factors that influenced the choice of respondents waste disposal method in table 6 showed that $30.9 \%$ of the methods of waste disposal identified in figure 4 above were influenced by the ability of respondents to afford cost of waste disposal, while $13.2 \%$ of the respondents' choice of waste disposal methods was due to the frequency of service provided by the waste managers. On the other hand, majority $55.9 \%$ of waste disposal methods adopted by the respondents were influenced by the proximity of disposal points to respondents' places of residence. It can be observed that distance to these facilities affected waste disposal methods used by the respondents. This finding support the findings of Taiwo (2014) and Fisher (2015) which revealed distance as the major factors affecting major source of domestic water in the study area.

Table 6. Factor Influencing Waste Disposal Method in Ilorin Metropolis Source: Author's Fieldwork, 2017

\begin{tabular}{|l|l|l|}
\hline Factors & Frequency & Percentage \\
\hline Proximity of residence & 228 & 55.9 \\
Affordability of service & 126 & 30.9 \\
Frequency of service provision & 54 & 13.2 \\
\hline Total & 408 & 100.0 \\
\hline
\end{tabular}

\section{Proximity to Waste Disposal Facilities in Ilorin Metropolis}

The result in figure 5 showed that $43.1 \%$ of the respondents agreed that the distance between their homes and point of waste disposal is between $3 \mathrm{~km}$ and $4 \mathrm{~km}$ while $49.0 \%$ of the respondents agreed that the distance between their places of residence and point of waste disposal is between $1 \mathrm{~km}$ and $2 \mathrm{~km}$. Only $1.5 \%$ of the respondents attested that the distance between their homes and point of waste disposal is above $8 \mathrm{~km}$. The implication of this is that since most of the respondents walks a long distance to points of waste disposal, disposing waste may become a tedious task, hence, individuals are likely not dispose their refuse for a long period of time and this may result to environmental pollution and in turn, pose risk to public health. 


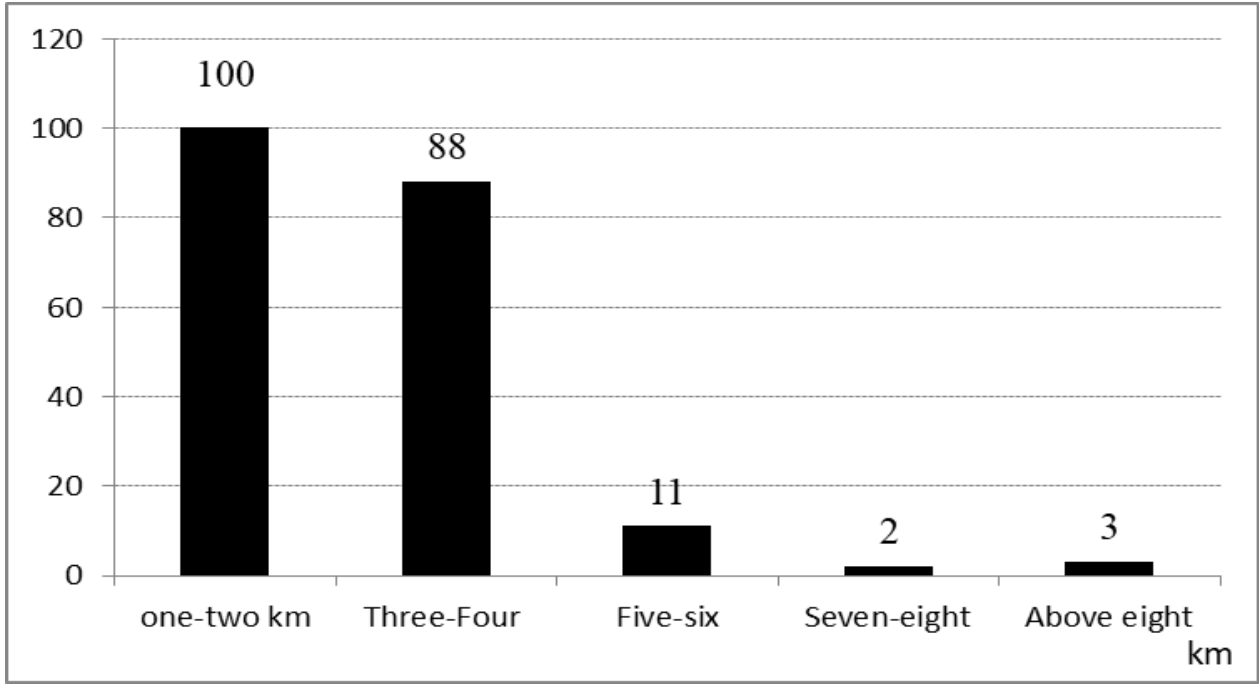

Figure 5. Proximity to Waste Disposal Facilities in Ilorin Metropolis Source: Author's Fieldwork, 2017

\section{Availability of Waste Disposal Facilities and Frequency of Waste Disposal in Ilorin Metropolis}

The findings in table 7 revealed that $26.0 \%$ and $21.1 \%$ of the respondents disagreed and strongly disagreed respectively that there are enough waste disposal facilities in the study area. The severity of the sanitation challenge facing urban areas in Nigeria can be judged from the fact that hardly one third of the overall population has easy access to sanitation facilities. On the other hand, $43.1 \%$ and $9.8 \%$ of the respondents claimed that they agreed and strongly agreed that there are enough waste management facilities in the study area. It can be observed from this data In addition, $4.7 \%$ of the respondents agreed that wastes generated in the study area are disposed daily, while $38.7 \%$ and $27.9 \%$ of the respondents agreed that most wastes generated in the study area are disposed weekly and more than a week respectively. This may be attributed to the fact that most of the wastes generated in the study area are collected by KWMC at a specific time and day in a week.

Table 7. Availability of Waste Disposal Facilities and Frequency of Waste Disposal in Ilorin Metropolis Source: Author's Field work, 2017

\begin{tabular}{|l|l|l|}
\hline Availability & Frequency & Percentage \\
\hline Strongly Agree & 40 & 9.8 \\
Agree & 176 & 43.1 \\
Strongly Disagree & 86 & 21.1 \\
Disagree & 106 & 26.0 \\
Total & 408 & 100 \\
\hline Frequency of Waste Disposal & & \\
\hline Daily & 60 & 14.7 \\
Twice per week & 76 & 18.6 \\
Weekly & 158 & 38.7 \\
More than a week & 114 & 27.9 \\
Total & 408 & 100 \\
\hline
\end{tabular}

\section{Efficiency of Access to Waste Disposal Facilities in Ilorin Metropolis}

With regards to the efficiency of the services provided by waste management agencies in the study area, majority (30.4\%) of the respondents considered the services as good, while $24.5 \%$ rated the service as averagely good (table 8 ). Also, $24.5 \%$ of the respondents were of the opinion 
that the services are poor and $8.8 \%$ of them considered it as worse. This implies that about onethird of the respondents are not satisfied with the services provided by waste management agencies in the study area.

Table 8. Efficiency of Access to Waste Disposal Facilities in Ilorin Metropolis Source: Author's Field work, 2017

\begin{tabular}{|l|l|l|}
\hline Factors & Frequency & Percentage \\
\hline Very Good (above 70\%) & 48 & 11.8 \\
Good (55-69\%) & 42 & 30.4 \\
Average (45-59\%) & 100 & 24.5 \\
Poor (40-44\%) & 100 & 24.5 \\
Worse (below 39\%) & 36 & 8.8 \\
\hline Total & 408 & 100.0 \\
\hline
\end{tabular}

\section{Ways to Improve Access to Waste Disposal Facilities in Ilorin Metropolis}

The results of ways to improve waste disposal facilities in the study area revealed that $25.0 \%$ of the respondents affirmed that in order to improve the quality of service provided by the waste management agencies in the study area, each community, through Community Developments Associations (CDAs) should be more involved. This may involve laying emphasis on the need for clean environments during household heads meeting at the community level. Also, figure 6 further revealed that $33.8 \%$ of the respondents were of the opinion that government should be more involved in waste management while $41.2 \%$ of them were of the view that government should be involved in adequate provision and proper distribution of waste disposal facilities in the study area.

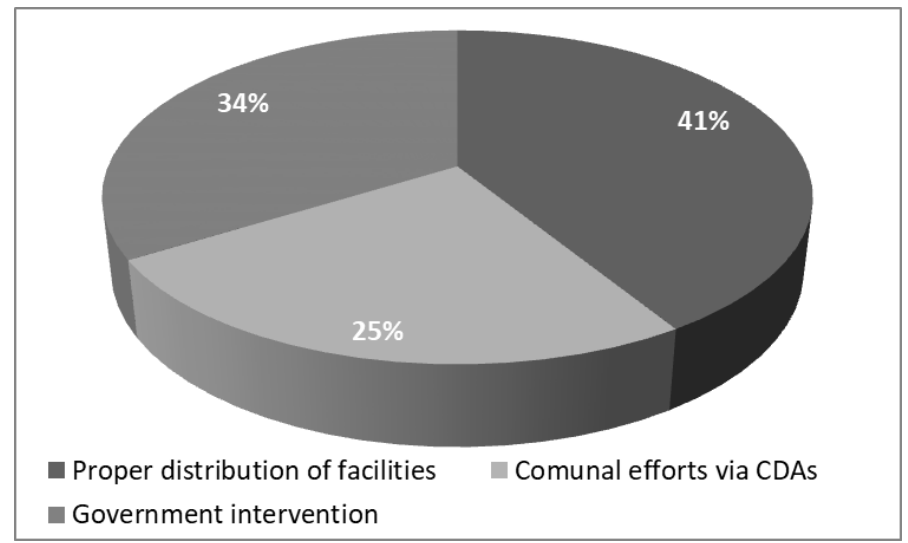

Figure 6. Ways of Improving Access to Waste Disposal Facilities in Ilorin Metropolis Source: Author's Fieldwork, 2017

\section{CONCLUSION}

It is clear that majority of people in Ilorin metropolis depend on Kwara State Government for infrastructural facilities like water supply and waste disposal facilities. The respondents in the study area are stressed before accessing both water supply and waste disposal facilities. This is because, majority of the residents spend 30 minutes or more and walk a long distance before getting to the nearest pipe borne water facility. Furthermore, wastes generated by residents and dumped in government provided disposal facilities are collected once in a week and most government owned waste disposal bins are not easily accessible for many households. The study thus recommends the provisions of more boreholes within the reach of the public and 
strengthens the existing water policy by ensuring adequate maintenance of water treatment plants. Also, the poor environmental habits of many Nigerians are embedded in their lifestyles, such as littering the streets with waste and burning of waste within the neigbourhood. Programs should be implemented to reward cash for waste cans and plastic bags supplied by individuals based on the weigh, providing incentive not to litter. This is another example of an indirect enforcement strategy.

\section{REFERENCES}

Ajibade, L. T. (2008). Waste ergonomics optimization in Ilorin, Nigeria. Ethiopian Journal of Environmental Studies and Management, 1(2), 83-92.

Akinwale, A. A. (2010). The menace of inadequate infrastructure in Nigeria. African Journal of Science, Technology, Innovation and Development, 2(3), 207-228.

Akinyosoye, M. (2010). Infrastructure development in Nigeria road map to sustainable development. Greenhill Technical Services.

Banji-Onisile, A. (2015). The Effect of Population Growth on Transportation: A Case Study of University of Ilorin Students. An Unpublished seminar paper presented at the Department of Geography and Environmental Management, University of Ilorin, Ilorin, Nigeria.

Dahlgren, G. (2008). Neoliberal Reforms in Swedish primary health care: for whom and for what purpose?. International Journal of Health Services, 38(4), 697-715.

Fisher, O. M. (2015) Analysis of the Efficiency of Domestic Water Supply in Ilorin metropolis, Nigeria. An unpublished B.Sc. Project. Department Geography and Environmental Management, Faculty of Social Sciences, University of Ilorin, Ilorin, Nigeria.

Ogu, V. I. (2009). Urban infrastructure development and sustainability in Nigeria. Human Settlement Development-Volume III, 109.

Omonona, B., \& Adeniran, O. (2012). Consumers' willingness to pay for improved water services in Ilorin metropolis of Kwara State, Nigeria. Journal of Economics and Sustainable Development, 3(9), 30-37.

Oyebode, R.A. (1991). Water Supply in Western Sector of Ilorin City. Unpublished B Sc. Thesis, Department of Geography and Environmental Management, University of Ilorin, Ilorin, Nigeria.

Penelope, B., \& Warrick, S. (2001). Improving Access to Infrastructure Service by the Poor. World Bank Project. Department Geography and Environmental Management, Faculty of Social Sciences, University of Ilorin, Ilorin. Nigeria.

Rutto, K.R. (1997). An Assessment of Infrastructure Services Provision and its Effects on the Growth of Urban Centres: A Case Study of Kipkelion, Kericho District. An unpublished M.A. Research Thesis, University of Nairobi, Kenya.

Sanni, M. A. (2014). Effects of rural migration on the population increase of Ilorin Metropolis. An unpublished B.Sc. Thesis, Department of Geography, Bayero University, Kano, Kano, Nigeria.

Taiwo, A.E. (2014). Influence of Access to Potable Water on Household Health in Ilorin. An unpublished B.Sc. Project. Department Geography and Environmental Management, Faculty of Social Sciences, University of Ilorin, Ilorin. Nigeria.

United Nation Department of Economic and Social Affairs (UN DESA, 2018). The 2018 Revision of World Urbanization Prospects Produced by the Population Division of the UN Department of Economic and Social Affairs. Retrieved online on 28th November, 2019 @ http:/www.un.org/development/desa/en/news/population/2018-revision-of-worldurbanization-prospects.html.

United Nations (2014). World Urbanization Prospects: The 2014 Revision, New York.

World Bank (2003). Infrastructure and environment, World Bank research development group, March. Washington DC: World Bank.

World Health Organization. (2020). State of the world's sanitation: an urgent call to transform sanitation for better health, environments, economies and societies.

Submitted:

November 25, 2019
Revised:

December 20, 2020
Accepted and published online January 22, 202 